\title{
The seismic activity in the area of Greece between 1966 and 1969
}

\author{
P. A. Giavinakopoulos * \\ Received on March $28^{\mathrm{th}}, 1972$
}

\begin{abstract}
Sumarr. - The earthquake activity in the area of Greece for the years 1966, 1967, 1968 and 1969 is investigated. This earthquake activity as a rule follows the general pattern found by the use of data for a much longer period. There is a clear tendency for the focal depth of the earthquakes to increase from the convex side of the Aegean arc to the inner volcanic arc.

The value of the constant $b$ of the recurrence curves is much smaller for the intermediate earthquakes than for the shallow ones.

Riassunto. - i stata studiata l'attività sismica in Grecia durante gli anni 1966, 1967, 1968 e 1969. Detta attività, come di consueto, segue il modello generale trovato usando i dati per un periodo di tempo piuttosto lungo.

La profondità focale dei terremoti ha una chiara tendenza ad aumentare dalla parte convessa dell'arco Egeo verso la parte più interna dell'arco vulcanico.

Il valore della costante $b$ delle curve di ricorrenza è molto più piccolo per i terremoti intermedi che per quelli superficiali.
\end{abstract}

\section{INTRODUCTION}

The area of Greece is an active part of the Alpide-HimalayanMelanesian belt. Its tectonic activity is demonstrated by several geophysical and geological evidence. The seismic activity of the area is considerable, too.

Investigation of the seismicity of the area was started in the end of the nineteenth century $\left({ }^{4}\right)$. Those studies, however, were based on inhomogeneous macroseismic data. After 1911, when two horizontal components of Mainka seismograph were put in regular operation in (Greece).

(*) National Observatory of Athens, Seismological Institute, Athens, 
Athens, systematic collection of microseismic data has been made, too.

On the basis of the data, collected between 1900 and 1962, and of some historic data as well Galanopoulos ${ }^{(1)}$ has investigated in detail the region bounded by the $34^{\circ} \mathrm{N}$ and $42^{\circ} \mathrm{N}$ parallels and by the $19^{\circ} \mathrm{E}$ and $29^{\circ} \mathrm{E}$ meridians. Papazachos and Comninakis $\left({ }^{2}\right)$ based on revised homogeneous data, concerning the period between 1911 and 1969 , were led to some interesting conclusions in respect to the spatial distribution of the earthquake foci.

The purpose of the present work is to investigate the seismic activity in the area of Greece between 1966 and 1969 and compare this short term activity with the results published previously by other authors.

THE DATA

In 1965 and 1968 the Seismological Institute of the National Observatory of $A$ thens established a network of six stations at several places in the area of Greece. With the data from these stations and the central station in Athens it is possible to determine with good accuracy the epicenters of all the shocks with magnitude $M \geqslant 4.4$ which occurred in the area bounded by the $34^{\circ} \mathrm{N}$ and $42^{\circ} \mathrm{N}$ parallels and by the $19^{\circ} \mathrm{E}$ and $29^{\circ} \mathrm{E}$ meridians. With this network of stations we can distinguish the intermediate $(\hbar>60 \mathrm{~km})$ from the shallow earthquakes. This network helps much to estimate the focal depth of the intermediate earthquakes.

These data are regularly published in the monthly bulletins of the Seismological Institute.

In the present work, data of earthquakes with magnitudes $M \geqslant 4.4$ have been used. Information for a few intermediate earthquakes with smaller magnitude has also been used.

The amplitudes of the two horizontal components of the WoodAnderson seismograph in Athens have been used to calculate the magnitudes of the shallow earthquakes.

The following relation has been used to calculate the magnitude of the intermediate earthquakes

$$
M_{L}=\log A+0.40 D+2.80
$$

where $D$ is the distance between the focus and the station of $A$ thens, and $A$ is the mean value of the maximum recorded amplitudes by the 
two components of the Wood-Anderson seismograph. The $A$ is measured in $\mathrm{mm}$ and $D$ in hundreds of $\mathrm{km}$.

To find the magnitude $M$ the value 0.44 was added to the magnitude $M_{L}{ }^{\left({ }^{3}\right)}$.

\section{THE SHALLOW EARTHQUAKES}

Figure 1, is an index map of the location of the epicenters of the shallow earthquakes which have been occurred in the area of and near

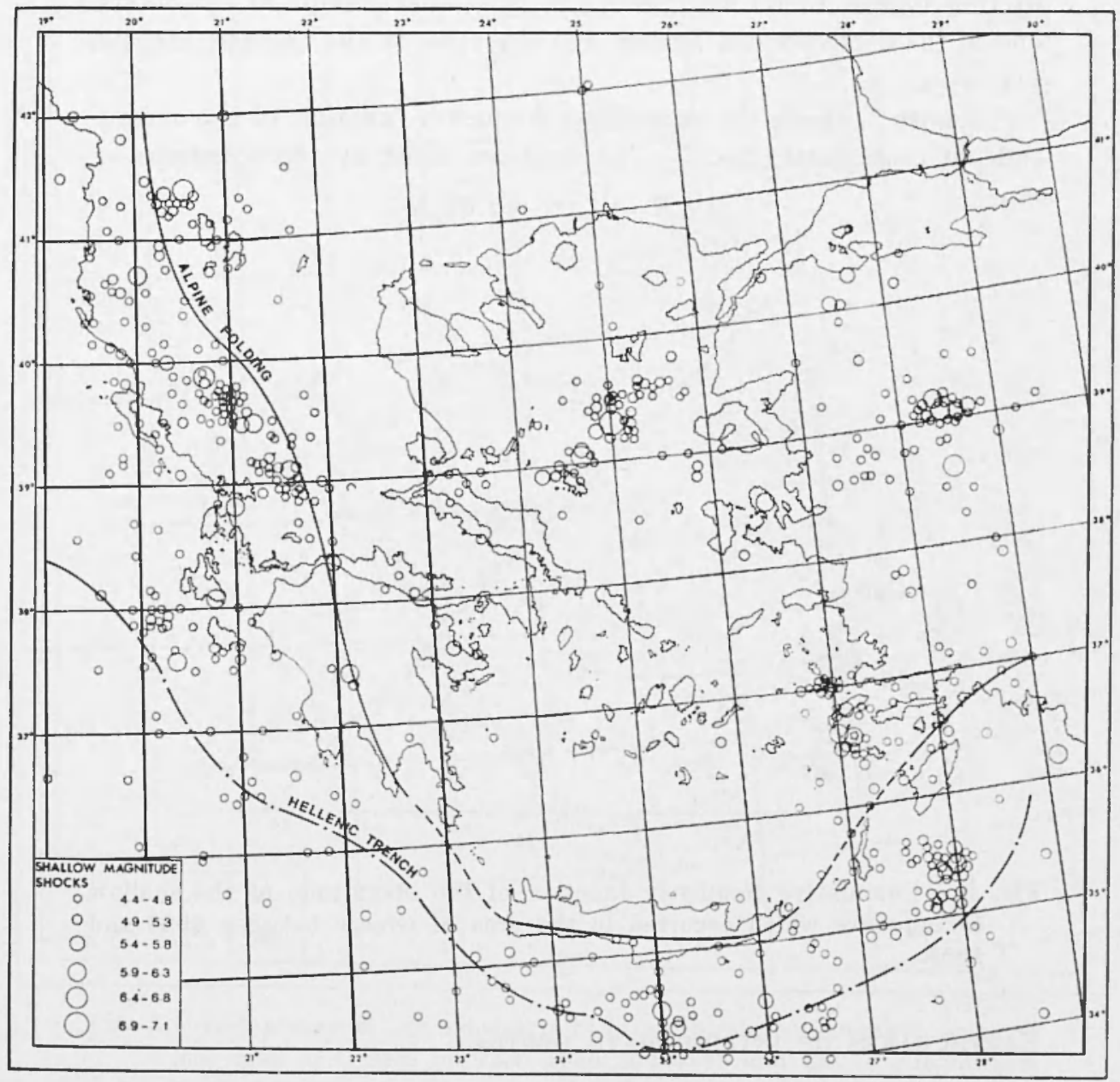

Fig. 1 - Index map of the epicenters of the shallow earthquakes which occurred in the area of Greece between 1966 and 1969. 
Greece in the years 1966, 1967, 1968 and 1969. In the same figure the trend of the main mountain range in the area, and the Hellenic trench are shown.

It is observed that the main seismic belt of the shallow earthquakes parallels the Alpine folding and lies on the seaward slope of the folding, that is, in the convex side of the Aegean island arc. Most of the epicenters in the western, southern and southeastern part of the region, lie in the landward slope of the Fellenic trench.

Except the above mentioned seismic zone, which is directly related to the Aegean island arc, there are two other groups of epicenters; one in the northwestern Turkey and the other in the northern Aegean sea.

Figure 2, shows the cumulative frequency function of the magnitude of these earthquakes. The data are fitted by the equation:

$$
\log N=7.18-1.01 M
$$

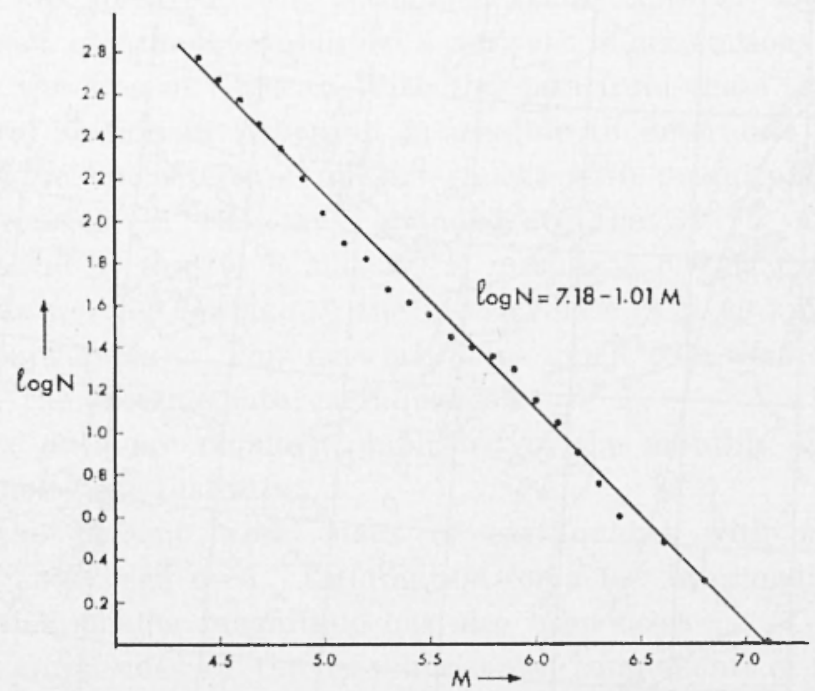

Fig. 2 - Cumulative frequency function of the magnitude of the shallow earthquakes which occurred in the area of Greece between 1966 and 1969 .

\section{EARTHQUAKES OF INTERMEDIATE DEPTHS}

Figure 3 , is an index map of the location of the epicenters of intermediate earthquakes of magnitudes $3.7 \leqslant M \leqslant 4.8$, which oc- 
cured in the area of Greece between 1966 and 1969. In the same figure the isodepths (lines of equal focal depth) of $150 \mathrm{~km}$ and $100 \mathrm{~km}$, determined by Papazachos and Comninakis $\left(^{2}\right)$ by the use of data of intermediate shocks with magnitudes $M \geqslant 4.9$ are shown.

In the map of figure 3 , three different symbols have been used to denote the earthquakes with focal depths between $50 \mathrm{~km}$ and

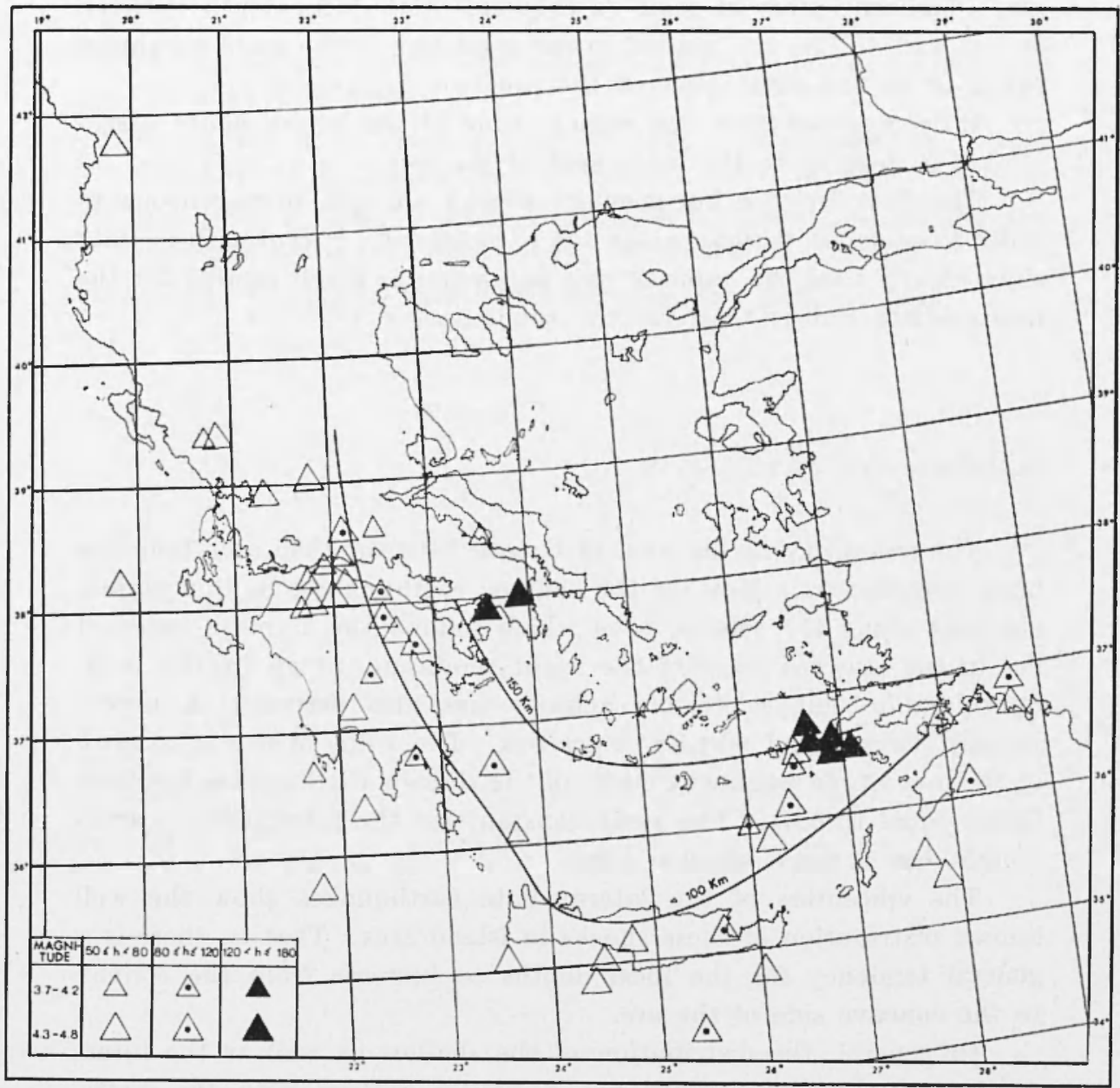

Fig. 3 - Index map of the epicenters of intermediate earthquakes occurred in the area of Greece between 1966 and 1969 and having magnitudes between 3.7 and 4.8 . The isodepths of $100 \mathrm{~km}$ and $150 \mathrm{~km}$ determined by Papazachos and Comninakis $\left({ }^{2}\right)$ on the basis of independent data are also shown. 
$80 \mathrm{~km}$, between $80 \mathrm{~km}$ and $120 \mathrm{~km}$, and between $120 \mathrm{~km}$ and $170 \mathrm{~km}$. These symbols have two sizes to represent two magnitude ranges.

The epicenters of all the earthquakes with focal depth larger than $120 \mathrm{~km}$, lie on an are which coincides with the volcanic arc. The epicenters of almost all the earthquakes with focal depth between $80 \mathrm{~km}$ and $120 \mathrm{~km}$ are located in the inner slope of the sedimentary arc. The epicenters of most earthquakes with focal depth between $50 \mathrm{~km}$ and $80 \mathrm{~km}$, are located in the crest line of the main mountain lange or in the onter part of the arc.

It is observed that the seismic zone of the intermediate earthquakes is deeping to the inner part of the arc.

The data for the intermediate shocks are not homogeneous in order to calculate with accuracy the parameter $b$. However these data show clearly that the value of this parameter is much smaller for the intermediate shocks than for the shallow ones.

SuMMARY AND CONClesions

The seismicity in the area of Greece between 1966 and 1969 has been investigated. Most of the shallow earthquakes, in this period, occurred along the seismic zone which follows the dynaric are and lies in the seaward slope of the main mountain range in the area. Considerable shallow seismic activity has also occurred in northwestern Turkey and northern Sporales. The value of the constant $b$ of the magnitude frequency curve of the shallow earthquakes has been found equal to 1.01. The same constant for the intermediate earthquakes has a much smaller value.

The epicenters of the intermediate earthquakes show the well known distribution of these shocks in island arcs. That is, there is a general tendency for the focal depths to increase from the convex to the concave sirle of the arc.

In general, the distribution of the shallow as well as the intermediate earthquake activity has a similar pattern with the distribution derived by the use of data of longer periods. This distribution agrees with the theory that an African lithospheric plate underthrusts the Eurasian plate under the Aegean island arc and that the African plate moves from the Mediterranean sea towards Europe. 
THE SEISMIC ACIIVITY IX THE ARLA OF GREECE BETWEEX 1966 AND 1969365

\section{ACKNOWLEDGEMENTS}

The author expresses his thanks to Dr. B. C. Papazachos for critical reading of the manuscript of the paper.

\section{REFERENCES}

(1) Galanopoulos A., 1963. - On mapping of the Seismic Activity in Greece, "Annali di geofisica", XVI, 1.

(2) Papazachos B. C., Conninakis P. E., 1971. - Geophysical and Tectonic Features of the Aegean Arc, "J. Gephrs. Res. ", 76, 35.

$\left({ }^{3}\right)$ Ronney C. F., 1964. - An Investigation of the Relationship between. Magnitudes Scales from small shocks, VESIAC Rep. 4410-71-X.

(4) Scrmidr I., 1879. - Studien über Erdbeben, 2nd Aufl., Leipzig. 